\title{
Urban regeneration of plants territories in industrial cities of Russia: a case study in Volgograd
}

\author{
Alexey Antyufeev ${ }^{1, *}$, and Galina Ptichnikova ${ }^{2}$ \\ ${ }^{1}$ Volgograd State Technical University, Department of Urban Studies and Theory of Architecture, 400074 Volgograd, Russia \\ ${ }^{2}$ Research Institute of Theory and History of Architecture and Urban Planning, Theory of Architecture Department, 111024 \\ Moscow, Russia
}

\begin{abstract}
Economic transformations and reorganizations of production led to the crisis of many industrial cities in Russia in the first decade of the 21 st century. This paper concerns the renovation of the former industrial zones located in coastal areas, which are very important for urban development of cities. In terms of socio-economic changes, this topic is relevant for many industrial cities of Volga region. The study is an attempt to find new roles in post-Soviet cities which face the problems of adapting to economic and social changes. The authors reveal the basic provisions of the project by the example of the renovation of the territory of the Metallurgical Plant "Red October" in Volgograd to alter the function to create a multifunctional cluster.
\end{abstract}

\section{Introduction}

At the beginning of the 21 st century, post-industrial cities are faced with the necessity of reorientation to diversified specialization, creation of human and social capital, improvement urban fabrics, and improvement interurban transport connections $[1,4,13]$.

Contemporary innovation economy requires a livable and prosperous urban environment for attracting and keeping high-skilled human capital [5, 14, 15]. The added value to cities and towns in Russian economy could be an initial impulse for launching drivers of the innovation economy [17].

Today many large cities in Russia began redeveloping their abandoned industrial areas [7, 9, 18]. This process could be called regeneration or renovation. The ongoing process de-industrialization which is freeing up areas in strategic urban places can provide with opportunity to re-assess the role, function and form of important part of the city [8, 19]. The gradual restructuring of some Post-Soviet industrial cities in recent years seem to point toward the relevance of new urban approaches. Different paths of development may only be explained from the distinctiveness of each territory, specific local decisions and successive strategies to tackle decay. These processes of revitalization seem to reveal the importance of local action and the possibility of guiding and easing decline [20]. Even more, they point out to the crucial role of urban planning [2].

The aim of this study is an attempt to reveal new practice, the new approach to regeneration of postindustrial areas in great Post-Soviet cities faced with the problems of adapting to economic and social changes.
The case study is in Volgograd, great industrial city with population of 1 million people. Volgograd is part of this urban trend, as it using many of its abandoned industrial zones.

\section{Post-Soviet industrial cities: Urban problems}

\subsection{Decay and abandoned industrial areas}

In Post-Soviet industrial cities many plants have been shut down; many industrial areas have been abandoned. Often these areas are located in strategic urban positions. They are areas which were once on the outskirts, but as cities spread they became more central and usually supplied with major urban infrastructure and connected by roads and railways. From their very outset the industrial areas were formed as enclosed enclaves and were seen as autonomous specialized areas distinct from rest the city

\subsection{Maintaining the Integrity of the Specifications}

The problem is especially acute in large cities of the Volga region. Historically feature of these cities is to place plants in coastal areas. The occupation of the coastal areas of industrial buildings was caused by the rapid industrial development of cities in the Volga to the 19 th and 20th centuries, as well as the extensive industrialization in the Soviet period [3]. New factories were located in coastal areas along the river, around a new large enterprise working village and serving

\footnotetext{
Corresponding author: antyufeevav@vgasu.ru
} 
infrastructure grew [10]. Then the industrial and residential area joined the city. For example, in Volgograd (former Tsaritsyn, then Stalingrad) during the industrial development of the largest giant plants - Steel ("Red October"), gun ("Barricades"), the Stalingrad Tractor (VPP), the chemical complex "Khimprom" are located along the Volga River (Fig.1).

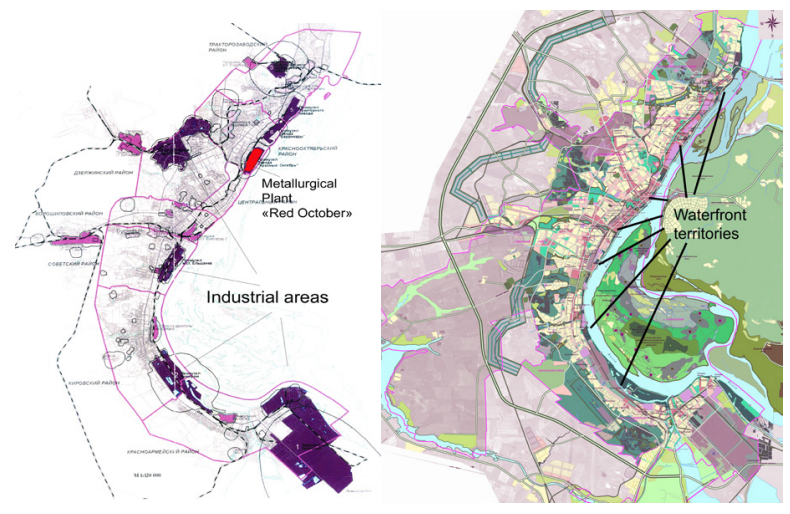

Fig. 1. Plan of waterfronts territories of Volgograd and Plan of locating the existing industrial zones situated on the coastal territories of the city, the most part of which are presently degrading post-industrial areas.

Currently Volgograd ceased to grow only at the expense of industrial giants. But at the same time, the city continues by inertia to grow further to the south and to the north, between its extreme points is almost a hundred kilometers.

Vast stretches of coastal area are still in the grip of production use or turned into a wasteland because of the decline in industrial production. The length of manufactured front in large industrial cities of the Volga region is $30 \%$ to $50 \%$ of the total coastline [6]. In Volgograd industrial areas occupy more than half of all coastal areas. The problem of creating social and recreational areas of coastal territories in Russian industrial cities situated along major rivers is presently one of the principal tasks which directly affect urban planning development of these cities [10]. Typical for this time of de-industrialization processes significantly influenced the image of many industrial cities of Volga region (Samara, Sizran, Saratov, Volzhsky).

Volgograd has known as an important industrial center and transport hub for more than a century. Today, Volgograd remains a bustling urban center and an industrial powerhouse of the Southern Federal District. So, for historical reasons, the Metallurgical Plant was situated along the Volga in city's north shore (Fig.2).
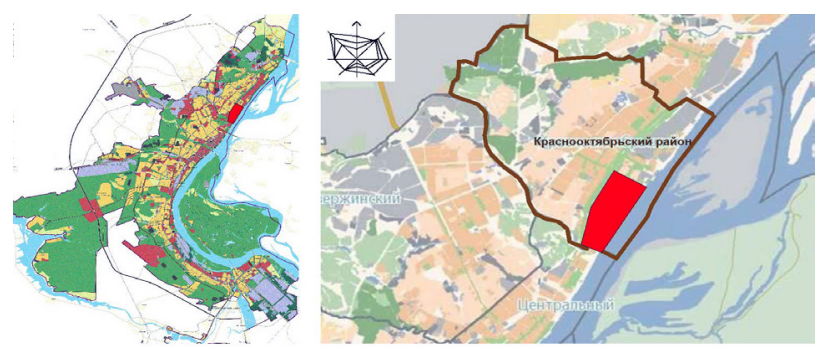

Fig. 2. Location of the Metallurgical Plant and selected study area.
The basis of Volgograd coastal industrial enterprises system is out-of-date. The planning structure of the existing coastal territory is characterized by the presence of randomly located territories of different use and purpose, low density of industrial development, and vast disrupted areas not using coastal territories as active public areas [16]. Today Volgograd is suffering from problem of decay tied to the lost its industrial base, but in the city we can find out of the beginning of a places of regeneration.

\section{Project of regeneration of the territory of the Metallurgical Plant "Red October"}

The project of urban regeneration of industrial territories of the Plant "Red October" was developed in Volgograd (Project Manager is professor Alexey Antyufeev).

The Metallurgical Plant was established in 1897 by the French joint stock "Ural-Volga metallurgical company". The plant was one of Russia's largest industrial facilities at the South. After the October Revolution the factory became known as "Krasny Oktyabr" ("Red October"). The factory was completely destroyed in the battle of Stalingrad, but was restored shortly after.

Currently, the plant is located in the central part of the city, directly adjacent to the Mamayev Kurgan, the stadium for 45000 spectators, projected to the FIFA World Cup 2018, and the coastal area along the Volga. The length along the river of plant facade is more than 3 kilometers. Industrial buildings, warehouses, office buildings, engineering infrastructure facilities occupy most of the territory of the plant. Currently, due to reduced steel production factory most of the territory, an area of 320 hectares, is in decay. Large areas are unused, production halls are empty buildings. This area with good transport accessibility and near the city center could not continue to be empty.

By order of the plant management the authors developed a renovation project with the formation of new functional areas, the relevant provisions of the existing Master Plan of Volgograd. The Red October regeneration plan was approved in 2015. The plan will be implemented in stages. In 2015, the project of sport complex was approved. The main goal now is to improve the transport infrastructure. Reorganization tasks and the creation of new connections have been solved for the optimal integration of the new public areas at the city planning structure. (Fig.3).

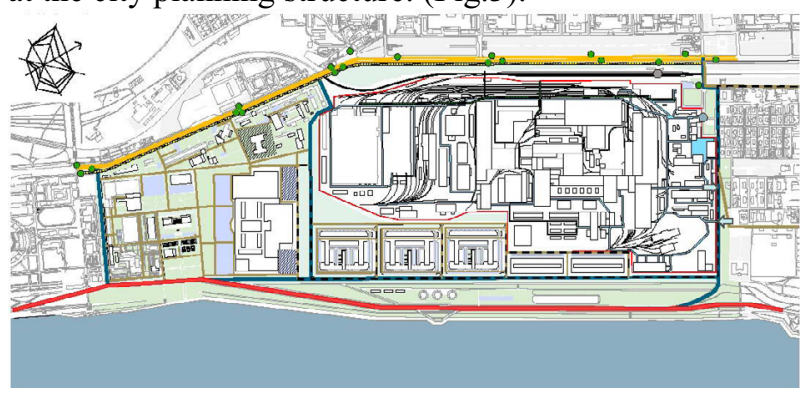

Fig. 3. Plan of modernization of transport infrastructure.of the Metallurgical Plant. 
The following problems were solved:

- functional reorganization of industrial areas;

- selection of the most effective option from an environmental point of view, the use of coastal areas and the organization of their accessibility to the public;

- the establishment of the planned development of the parameters of the elements of the newly formed planning structure.

It was decided to establish a public area with a focus on the creation of a sports cluster on liberated from the industrial production area of 160 ha [14]. Reconstruction of the repair center with span structures allowed creating space for a universal sports complex citywide importance, including basketball club and other facilities for training children and youth sports. This complex will join the sports zone that is generated around the stadium for the 2018 World Cup, of which the matches will be held in Volgograd. As additional functions exposition and exhibition facilities, shopping mall and two industrial parks were designed.

The transport infrastructure is being developed at a dynamic pace. In 2017-2018 there will be $15 \mathrm{~km}$ of new roads and The Rockada road along the river. The authors proposed the formation of a new section of the pedestrian promenade where it is supposed to create a center of extreme sports with the use and adaptation of existing cooling towers smelter.

In this way this practice shows new urban model of regeneration of post-industrial areas for community use. In was determined of some design approaches (Fig.4). First of all, it is the restoration of important industrial building for public uses. Secondly, project has been developed on brown fields to retrieve the sites to the community through its reuse as pedestrian promenade and recreational areas.

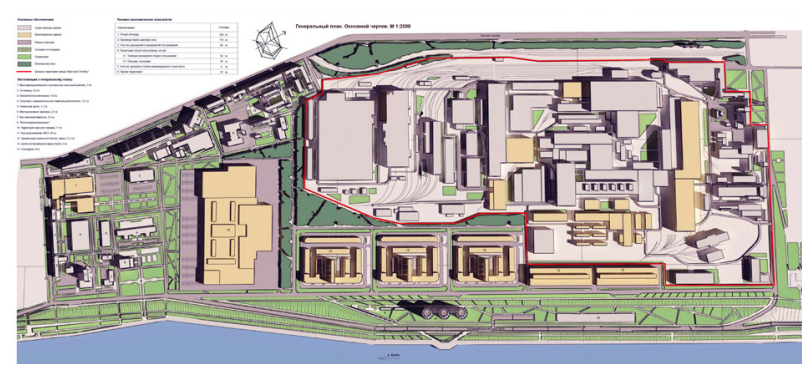

Fig.4. Master Plan of regeneration of post-industrial territories.

\section{Conclusions}

In Post-Soviet period industrial cities have seen fundamental economic restructuring. The weaknesses of these cities are their strong dependence from industries which have been created under another ideological, economic and planning rule without concern of transportation cost. Recently, various urban oriented initiatives have emerged in different cities. New approaches to solving the problems are revealed by the example of the project of regeneration of industrial areas of Volgograd plant "Red October".

The project has been an opportunity to link landscape architecture, environment restoration of polluted industrial areas and increase of parks and open spaces. Redeveloping industrial area will help improve the investment climate in the city.

To sum up, it seems to conclude that there are certain urban approaches and techniques that can help to face urban and economical decay. They would be:

1. Projects related to different aspects of the regeneration process. They are linked to Regional economic revitalization plans. These projects try to create a new regional economic base as diversified as possible. There are some kinds of development of new public activities.

2. Industrial Culture and Museum Programs. They linked to the restoration and reuse of important industrial heritage $[11,12]$. Most important industrial buildings are reconstructed for tourism, cultural uses and renovation for new public services.

Therefore urban planning has some basic techniques to cope with decline of post-industrial cities. An urban model can help these cities become complex and more sustainable. The emerging practice shows that urban discourse is getting the force and become an actual topic for discussion on the problem of economic regeneration of industrial cities.

\section{References}

1. B. Aguenda, The Archivo Digital UPM (2009). http://oa.upm.es/5976/1/FernandezAgueda_ponencia 2009.pdf

2. B. Aguenda, Territoire en Mouvement, 23-24 (2014) https://tem.revues.org/2527

3. A.V. Antyufeev, Biosphere compatibility: people, region, technology, 1, 100-105 (2015)

4. D. Brady, M. Wallace, Sociological Forum, 16(2), 321-358 (2001)

5. J. Friedrichs, Urban Studies, 30(6), 907-917 (1993)

6. S.S. Frolov, Urban planning reconstruction of coastal industrial territories of the largest cities (by the example of Volgograd) (SPbGASU, St. Petersburg, 2005)

7. C. Horn, Urban planet. http://urbanplanet.info/urbanism/potential-moscowsindustrial-zones-russia/

8. G. Garofoli, Ristrutturazione industriale e territorio (Franco Angeli Editore, Milano, 1978)

9. D.V. Knyazev, The economy of the region, $\mathbf{1 8}$ (2007). http: //journal.vlsu.ru/index.php id = 1732

10. E.E. Krasilnikova, A.V. Antyufeev, Strategic decision making on spatial development (ROAD/SPECTRA Centrum Excellencies, STU, Bratislava, 2014)

11. Y.H. Lou, X.Q. Zhu, F. Zhou, 2010 International Conference on Mechanic Automation and Control Engineering, 829-832 (2010)

12. O. Mamleyev, Architecture. Building. Design, 1(23), 21-27 (2001)

13. H. Molotch, American Journal of Sociology, 82(2), 309-332 (1976) 
14. M.E. Porter, Clusters and the new economics of competition (Harvard Business Review, Watertown, 1998)

15. G.A. Ptichnikova, Modern architecture world, 3, 177-190 (2013)

16. G.A. Ptichnikova, A.V. Antyufeev, Sociology of the city, 2, 5-19 (2014)

17. E. Rullani, Complexity and industrial clusters (Physica-Verlag, New York, 2002)
18. N.N. Sinitsyna, Architecton: Math. Universities, 1 (2004). http://archvuz.ru/numbers/2004_1/k23

19. J.W.R. Whitehand, N.J. Morton, Environ. Planning B, Planning Design, 30(6), 819-839 (2003)

20. Th. Wiechmann, K. Pallagst, International Journal of Urban and Regional Research, 32(2), 261-280 (2012) 